Proceedings

\title{
Semiconductor laser resonator for magneto-optic floppy disk head 光磁気フロッピーディスク用半導体レーザ共振器
}

Ryo TATEN0, Kunio USUI, Toshihisa SAT0 and Kenya GOT0

Department of information and communication technology, Tokai University, 317, Ni shino, Numazu, Shizuoka, 410-03 JAPAN

TEL:81-559-68-1211(EX. 4426), FAX:81-559-68-1155

( Accepted for publication 16 November 1995 )

A basic reserch with a new method to detect magneto-optical signals using an external cavity laser diode is performed. The magneto-otical signal is detected as the frequency shift of a beat signal. Because of its simple structure and large frequency shift for small Kerr rotation angle, a highly sensitive optical head is possible.

key words:External cavity, Magneto-0ptical signal, Kerr rotation angle

\section{I . Abstract}

半導体レーザチップに多層薄膜をコートし たレンズレス光磁気ヘッドを用い、カー回転 に応じたレーザの発振周波数変化を検出する 新方式を提案する。

II. Lens less magneto-optical head

L Dチップの両射出端面に多層薄膜を形成 LFig. 1 に示すように光F D 側が半導体レー ザチップの上に蒸着した反射防止膜 ( A R C ) 複屈折材料 ( Q W P ) 、反射防止膜 ( A R C ) であり、反射側が L D チップ端にコーティン グした反射防止膜（AＲＣ）、複屈折性材料 ( Q W P ) 、反射防止膜（A R C )、ファラ デーローテータ用材料、部分透過膜で構成さ れている。

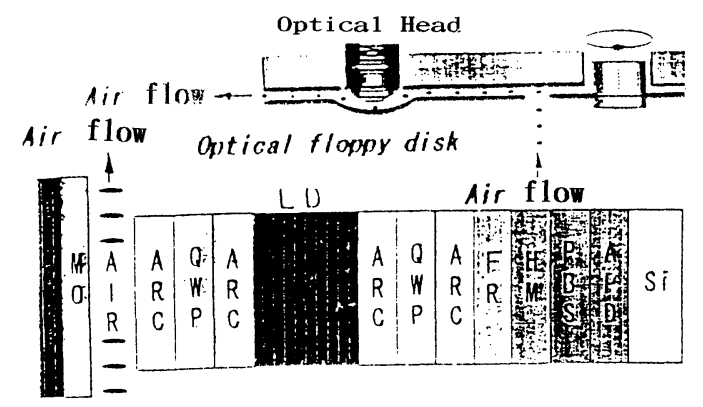

FIG. 1. Multilayered structure of lens less magneto-optical head

III. Magneto-optical signals detect principle

Figure. 2 に原理図を示す。本光磁気へッ ドは光磁気媒体と半透過鏡間に両端面反射防 止膜を施したL Dチップ、ファラデー回転子、 $\lambda / 4$ 板を配置した複合共振器 L D を構成し ている。L D の偏光状態は T Eモードである。 外部鏡と L D チップ両端面の間に $\lambda / 4$ 板を
方位 45 度で挿入することにより、L D 内部 で T E - T M 直交直線偏光を強制的に同時発 振させることができる。T E-T M モードは $\lambda / 4$ 板を通過後、左右円偏光に変換され両 モード間に磁気カー効果による位相差が生じ る。このことから T E - T Mモードが僅かに 異なる周波数で同時発振する。半透過鏡を通 過した直交偏光間のビートを検出することに より光磁気ディスク表面における磁気力ー効 果による偏光面の回転を電気的ビート信号と して検出することができる。2

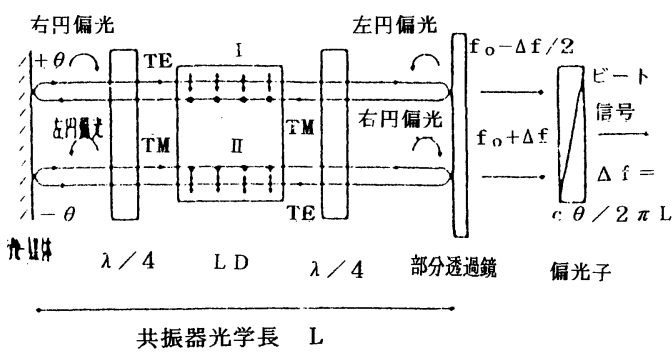

FIG. 2. Principle of lens less magnetooptical head

IV. Conclucion

新しい方式のレンズレス光磁気ディスクヘッ ドの提案を示した。今後は、多層薄膜集積化 レーザの試作ならびに光磁気信号の検出実験 を行いたい。

Referrences

1 K. Goto, T. Sato, S. Mita; Jpn. J. App1. Phys. 32(1993)5459, part 1, No. 11b(Nov. 1993).

${ }^{2}$ N. Fukushima and I. Sasaki :Microoptics News, 6, No. 3(Sept. 1988)204.

'95 SAS Intelligent Symposium 